\title{
Generation of long tracts of disease-associated DNA repeats
}

\author{
Seung-Hwan Kim¹, Lu Cai ${ }^{2}$, Malgorzata J. Pytlos ${ }^{1}$, Sharon F. Edwards ${ }^{1}$, and Richard R. Sinden ${ }^{1}$
}

BioTechniques 38:247-253 (February 2005)

\begin{abstract}
The generation of long uninterrupted DNA repeats is important for the study of repeat instability associated with several human genetic diseases, including myotonic dystrophy type 1. However, obtaining defined lengths of long repeats in vitro has been problematic. Strand slippage and/or DNA secondary structure formation may prevent efficient ligation. For example, a purified $(C T G)_{140^{\bullet}}(C A G)_{140}$ repeat fragment containing 4-bp AGCA/TGCT overhanging ends ligated poorly using T4 or Escherichia coli DNA ligase, although limited repeat ligation occurred using thermostable DNA ligase. Here we describe a general procedure for ligating multimers of DNA repeats. Multimers are efficiently ligated when slippage is prevented or when DNA repeats contain a single G/C overhang. A cloning vector is designed from which pure repeat fragments containing a G/C overhang can be generated for further ligation. $(C A G)_{n} \bullet(C T G)_{n}$ DNA molecules longer than $800 \mathrm{bp}$ were generated using this approach. This approach also worked for $(G A A)_{n} \bullet(T T C)_{n},(C C T G)_{n} \bullet(C A G G)_{n}$, and $(A T T C T)_{n} \bullet(A G A A T)_{n}$ tracts associated with Friedreich ataxia, DM2, and spinocerebellar ataxia type 10 , respectively.
\end{abstract}

\section{INTRODUCTION}

DNA repeat expansions are associated with many genetic neurodegenerative diseases and three fragile sites (1-4). Long disease-relevant repeats often possess unique properties including the ability to form alternative DNA secondary structures that may contribute to their instability. Biophysical and biochemical studies have shown that the disease-associated DNA repeats form several secondary structures, including hairpins, parallel DNA, triplex DNA, quadruplex DNA, slipped-strand DNA, and unpaired DNA structures (5-10). The probabilities of secondary structure formation and genetic instability are generally proportional to repeat length $(6,9-11)$.

For the identification of molecular mechanisms involved in trinucleotide repeat instability leading to disease, the generation of long pure trinucleotide repeats has been an essential but difficult step, even though different methods have been employed (12-18). The problem of generating proteins containing long tracts of Gln encoded by CAG repeats has been solved by cloning Gln-encoding tracts that are not pure repeats $(19,20)$. In Escherichia coli, the maximum number of $(\mathrm{CTG})_{\mathrm{n}} \cdot(\mathrm{CAG})_{\mathrm{n}}$ repeats that can be maintained ranges from 180 to 240 , and these are typically stabilized by sequence interruptions within the repeat tract (12). Pure CTG tracts have been produced in vitro by thermal cycling protocols $(21,22)$. A similar procedure has been used to generate long ATTCT repeats (23). In addition, a pure (CTG) 250 tract was made by the dimerized ligation of CTG repeats $(17,18)$. Because cells from patients with these disorders maintain thousands of repeats, the generation of pure repeat tracts, longer than those stably maintained in bacteria, would be useful for mammalian cell studies, in which thousands of repeats are relatively stable. Here we discuss how technical difficulties encountered in the cloning of longer repeat DNAs may result from strand slippage of pure duplex repeats, which can change the nature of the overhang at the ends of the DNA molecules. We describe procedures for cloning pure repeats in $E$. coli as substrates for subsequent ligation in vitro to generate tracts of 800 repeats or more.

\section{MATERIALS AND METHODS}

\section{Plasmids and Escherichia coli Growth Conditions}

Plasmid pACT, kindly provided by Dr. Charles A. Thornton (Neuromuscular Disease Center Clinic, University of Rochester, Rochester, NY, USA), contains $\quad 130-140 \quad(\mathrm{CAG}) \cdot(\mathrm{CTG})$ repeats inserted between the $B b s \mathrm{I}$ and $B s a \mathrm{I}$ sites in plasmid pACYC177. Transformed cells (E. coli DH5 $\alpha$ or HB101) were grown in Luria-Bertani (LB) broth (10 $\mathrm{g} \mathrm{Bacto}^{\circledR}$ tryptone, 5 $\mathrm{g}$ yeast extract, $10 \mathrm{~g} \mathrm{NaCl}$ per liter of water) supplemented with $10 \mu \mathrm{g} / \mathrm{mL}$ kanamycin at $30^{\circ} \mathrm{C}$ and harvested before the cultures reached stationary phase $\left(\mathrm{A}_{650}\right.$ of 0.7$)$, conditions important for maintaining the stability of repeats in E. coli.

\section{Plasmid Purification}

We utilized an alkaline lysis method for purifying plasmid DNA (24), with slight modification. A 500-mL culture was grown in LB, supplemented with $10 \mu \mathrm{g} / \mathrm{mL}$ kanamycin for pACT and

${ }^{1}$ Texas A\&M University System Health Science Center, Houston, TX, USA and ${ }^{2}$ Inner Mongolia University of Science and Technology, Inner Mongolia, P.R. China 
$(\mathrm{CAG})_{130-140} \bullet(\mathrm{CTG})_{130-140}$ fragment was incubated with $400 \mathrm{U}$ T4 DNA ligase (New England Biolabs, Beverly, MA, USA or Roche Applied Science, Indianapolis, IN, USA) or $10 \mathrm{UE}$. coli DNA ligase (New England Biolabs) in the supplied buffer in $20 \mu \mathrm{L}$ for 16,24 , or $48 \mathrm{~h}$ at $4^{\circ}$ or $16^{\circ} \mathrm{C}$ (Figure $1 \mathrm{~B}$ ). For high-temperature ligation, $1 \mu \mathrm{g}$ of the gel-purified $(\mathrm{CAG})_{130-140} \cdot(\mathrm{CTG})_{130-140}$ fragment was incubated with 5,10 , 15,20 , or $25 \mathrm{U}$ of thermostable DNA ligase from Thermus scodoductus (Roche Applied Science) at $37^{\circ}, 45^{\circ}$, $55^{\circ}$, or $65^{\circ} \mathrm{C}$ with or without heating at $95^{\circ} \mathrm{C}$ for $5 \mathrm{~min}$ (Figure 1B). Hightemperature ligation on a DNA thermal cycler (GeneAmp ${ }^{\circledR}$ PCR System 9700; PE Applied Biosystems, Foster City, CA, USA) utilized one microgram of $(\mathrm{CTG})_{130-140} \cdot(\mathrm{CAG})_{130-140}$ fragment and $5,10,15,20$, or $25 \mathrm{U}$ of the thermostable DNA ligase at $95^{\circ} \mathrm{C}$ for $20 \mathrm{~s}$ and $60^{\circ}, 65^{\circ}$, or $77^{\circ} \mathrm{C}$ for $30 \mathrm{~min}$. This cycle was repeated $15-30$ times.

Cloning $(\mathrm{CAG})_{\mathrm{n}} \bullet(\mathrm{CTG})_{\mathrm{n}}$ tracts containing $\mathrm{G} / \mathrm{C}$ overhanging ends.
pLC plasmids, derived from pUC8, contain 5'-AATTCGAGTCGCG CG(CTG) ${ }_{n}$ GCGCGACTCGG-3' between the EcoRI and BamHI sites. pLCctg7, pLCctg27, and pLCctg44, contain 7, 27, and 44 (CAG)•(CTG) repeats, respectively. These plasmids were constructed by the ligation of $(\mathrm{CAG})_{7} \bullet(\mathrm{CTG})_{7}$ fragments flanked with $\mathrm{G} / \mathrm{C}$ overhanging ends, formed by hybridization of $(\mathrm{GCT})_{7}$ and $(\mathrm{CAG})_{7}$ (The lengths of cloned repeat tracts are frequently a bit different from that expected, given the genetic instability of these sequences.) One to six micrograms of oligonucleotides (18-20 nucleotides) were phosphorylated using $1.5 \mathrm{mM}$ ATP and $10 \mathrm{U}$ T4 polynucleotide kinase in a $20-\mu \mathrm{L}$ reaction volume (New England Biolabs). The DNA was precipitated with ethanol and then resuspended in $20 \mu \mathrm{L}$ of TEN. Complementary pairs of oligonucleotides in TEN $(2-12 \mu \mathrm{g}$ in $40 \mu \mathrm{L})$ were hybridized by boiling for $3 \mathrm{~min}$ and then slowly cooled overnight to $4^{\circ} \mathrm{C}$. The annealed DNA fragments $(3 \mu \mathrm{g})$

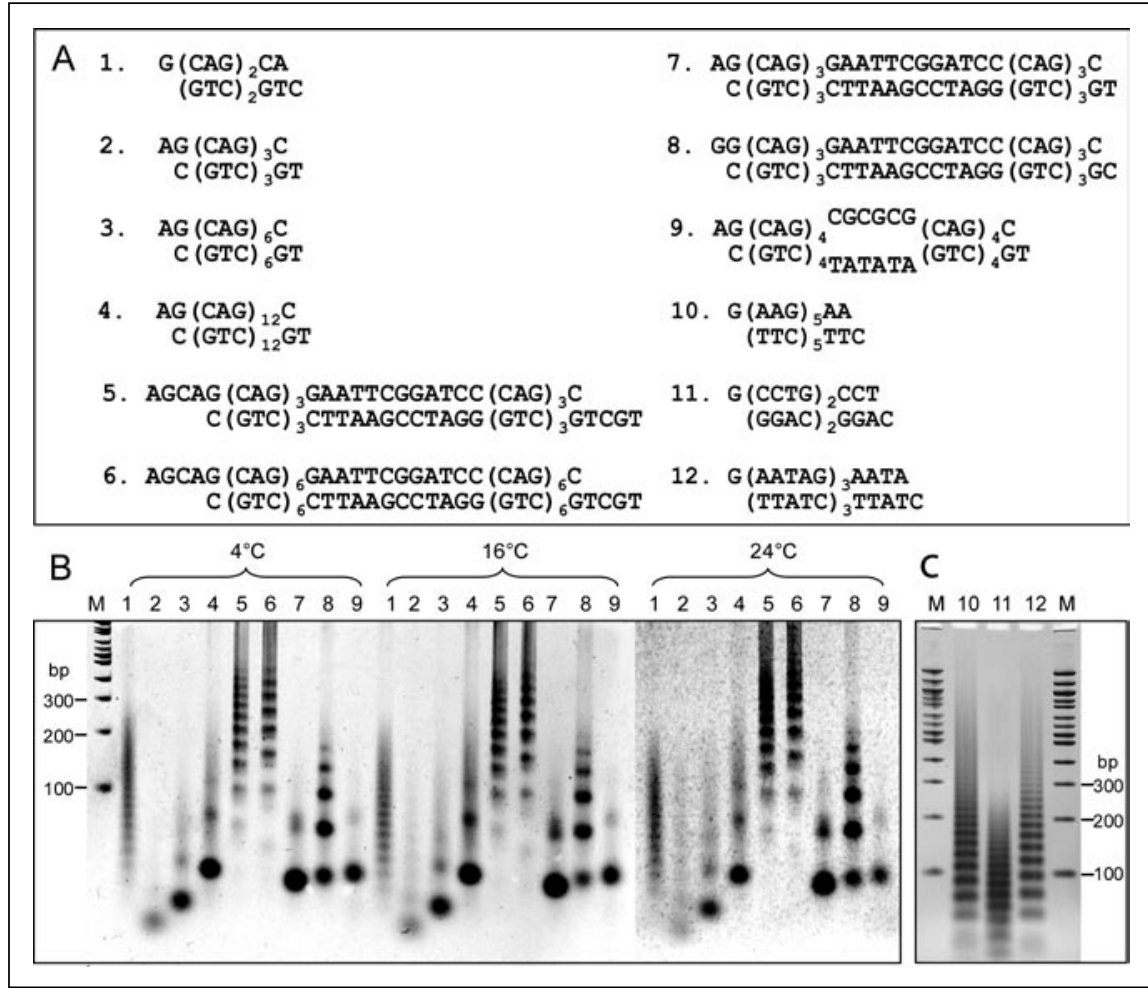

Figure 2. Ligation of annealed oligonucleotides containing different overhanging ends. (A) Synthesized oligonucleotide pairs creating DNA fragments 1-12 were mixed, boiled, and annealed by slowly cooling to $4^{\circ} \mathrm{C}$. The oligonucleotides were designed to contain one-base overhanging ends (1-4 and $7-12$ ) or four-base overhanging ends (5 and 6). (B) Oligonucleotides 1-9 were ligated using T4 DNA ligase at $4^{\circ}, 16^{\circ}$, or $24^{\circ} \mathrm{C}$ for $12 \mathrm{~h}$ and separated on a $10 \%$ polyacrylamide gel. (C) Oligonucleotides $10-12$ were ligated at $16^{\circ} \mathrm{C}$. M, molecular weight marker (100-bp ladder). were ligated to an EcoRI-PleI adaptor $(0.3 \mu \mathrm{g})$ formed by hybridization of 5'-GGAATTCGAGTCGCGC-3' with $5^{\prime}$-CGCGCGACTCGAATTCC-3' at a 1:10 (adaptor to repeat) weight ratio using $400 \mathrm{U}$ of T4 DNA ligase in $20 \mu \mathrm{L}$ at $16^{\circ} \mathrm{C}$ for $1 \mathrm{~h}$. This was followed by the addition of a BamHI-PleI adaptor $(0.6 \mu \mathrm{g})$ formed by the hybridization of 5'-GGCGCGACTCGGATCCG-3' and $5^{\prime}$-CGGATCCGAGTCGCGC-3' at twice the concentration of the first adaptor (1:10:2 weight ratio), and ligation was continued for 1 additional hour. After ligation, the DNA was digested with EcoRI and BamHI and ligated into pUC8 that had also been digested with EcoRI and BamHI. The length and purity of the repeat tracts were determined by dideoxy DNA sequencing.

For secondary cloning of longer repeats, the repeat sequences in pLCbased plasmids were amplified by PCR using two primers, 5'-GGAATTCGAGTCGCGC-3' and 5'-CGGATCCGAGTCGCGC-3' (two of the oligonucleotides used for linker construction). For PCR, REDTaq ${ }^{\mathrm{TM}}$ (Sigma, St. Louis, MO, USA) was used as directed with denaturation for $2 \mathrm{~min}$ at $94^{\circ} \mathrm{C}$; 30 cycles of $94^{\circ}$ for $30 \mathrm{~s}, 50^{\circ}$ for $30 \mathrm{~s}$, and $72^{\circ} \mathrm{C}$ for $2 \mathrm{~min}$; followed by a final extension at $72^{\circ} \mathrm{C}$ for $5 \mathrm{~min}$. The PCR products were digested with $P l e \mathrm{I}$, and then the DNA fragments containing $(\mathrm{CAG})_{\mathrm{n}} \bullet(\mathrm{CTG})_{\mathrm{n}}$ fragments with $\mathrm{G} / \mathrm{C}$ overhanging ends were ligated and separated on a $5 \%$ polyacrylamide gel. The ligation products purified from the gel as previously described (25) were cloned into the EcoNI site of pLCPNP. pLC-PNP contains the sequence 5'-GAATTCGAGTCCTGGGGGAGGACTCGGATCC-3' cloned between the EcoRI and BamHI sites of pUC8. This insert contains an EcoNI site flanked by two PleI sites. It is designed such that a pure repeat with a single G/ $\mathrm{C}$ overhanging end can be ligated into the EcoNI site and then cut out using PleI to regenerate the G/C overhang.

\section{Agarose and Polyacrylamide Gel Analysis}

The ligation products of DNA repeat fragments were analyzed by separation on a $1.2 \%$ agarose gel by electropho- 
resis in TAE buffer (15 mM Tris, $\mathrm{pH}$ $7.8,33 \mathrm{mM}$ Na acetate, $2 \mathrm{mM}$ EDTA) at $7 \mathrm{~V} / \mathrm{cm}$ for $2 \mathrm{~h}$ at room temperature. The ligation products were analyzed by separation on a $10 \%$ native polyacrylamide gel by electrophoresis in TBE buffer $(90 \mathrm{mM}$ Tris, $\mathrm{pH} 8.3,90 \mathrm{mM}$ boric acid, $2.5 \mathrm{mM}$ EDTA) at 8-10 $\mathrm{V} / \mathrm{cm}$ for $2-3 \mathrm{~h}$ at room temperature. The gels were stained with ethidium bromide and visualized.

\section{RESULTS}

\section{Ligation of the (CAG) $130-140^{\circ}$ (CTG) 130-140 Fragment}

To obtain long pure $(\mathrm{CAG}) \bullet(\mathrm{CTG})$ repeats in vitro, $(\mathrm{CAG})_{130-140^{\circ}}$ (CTG) $)_{130-140}$ fragments flanked with four-base overhanging ends (AGCA/ TGCT) were purified with a $1 \%$ agarose gel after digestion of pACT with $B b s \mathrm{I}$ and $B s a \mathrm{I}$ (Figure 1A). Ligation was then performed as previously described (17). The gel-purified (CAG) $130-140^{\circ}$ (CTG) ${ }_{130-140}$ fragments were ligated using T4, E. coli, or thermostable DNA ligases. However, following ligation by $\mathrm{T} 4$ and $E$. coli DNA ligases at $4^{\circ}$ or $24^{\circ} \mathrm{C}$, only about $5 \%$ of the fragment was ligated (Figure 1B). Ligation may be prevented by the formation of secondary structures within the $(\mathrm{CAG})_{130-140^{\circ}}(\mathrm{CTG})_{130-140}$ fragments or slippage of the fragment leading to a single $\mathrm{A} / \mathrm{T}$ overhang at the $5^{\prime}$ ends of the top and bottom strands. To test if the block to ligation could be alleviated by a high-temperature ligation, which may melt potential secondary structures at the DNA ends or promote slippage, we performed ligation using a thermostable ligase at high temperature. The melting temperature $\left(\mathrm{T}_{\mathrm{m}}\right)$ of $(\mathrm{CAG})_{130-}$ ${ }_{140^{\circ}}$ (CTG) ${ }_{130-140}$ in $6 \mathrm{mM} \mathrm{NaCl}$ (diluted from the storage buffer containing 100 $\mathrm{mM} \mathrm{NaCl}$ of Tsc thermostable ligase) is approximately $87^{\circ} \mathrm{C}$. The $\mathrm{T}_{\mathrm{m}}$ is given by $\mathrm{T}_{\mathrm{m}}=81.5+0.41(\% \mathrm{GC})-500 / \mathrm{L}+$ $16.6 \log [\mathrm{M}]$ where $\mathrm{L}$ refers to the length of oligonucleotide, $\mathrm{GC}$ is the $\mathrm{G}+\mathrm{C}$ content, and $[\mathrm{M}]$ is the concentration of monovalent cations, in this case $\mathrm{Na}^{+}$. Based on the high $\mathrm{T}_{\mathrm{m}}$ of $87^{\circ} \mathrm{C}$, the ligation using thermostable DNA ligase was performed by 15 cycles of incubation at $95^{\circ}$ for $20 \mathrm{~s}$ and $65^{\circ} \mathrm{C}$ for $30 \mathrm{~min}$. From densitometric analysis of the distribution of DNA in individual lanes using ImageQuant ${ }^{\circledR}$ software (Amersham Biosciences, Piscataway, NJ, USA), $40 \%-50 \%$ of the (CAG) $130-$ ${ }_{140}{ }^{\circ}$ (CTG) ${ }_{130-140}$ fragments appeared to have been ligated into multimers under these conditions in the reaction using $25 \mathrm{U}$ (Figure 1C). At least $15 \mathrm{U}$ of the thermostable ligase were required for optimal ligation (Figure 1C). When the denaturation time was increased from $20 \mathrm{~s}$ up to $5 \mathrm{~min}$ or the denaturation temperature was decreased from $95^{\circ}$ to below $89^{\circ} \mathrm{C}$, ligation did not occur (data not shown). Therefore, to obtain long trinucleotide repeats in vitro by ligation of (CAG) ${ }_{130-140^{\circ}}(\mathrm{CTG})_{130-140}$ fragments, the optimal conditions were a short denaturation at $95^{\circ}$ for $20 \mathrm{~s}$ and ligation at $65^{\circ} \mathrm{C}$ with thermostable DNA ligase. These results demonstrate that thermostable DNA ligase and a thermal cycling procedure can be used to improve the ligation of long pure $(\mathrm{CAG})_{\mathrm{n}} \cdot(\mathrm{CTG})_{\mathrm{n}}$ repeats in vitro.

\section{Ligation of DNA Repeats Containing a One-Base G/C Overhang}

It was possible that the initial fourbase $5^{\prime}$-AGCA $/ 5^{\prime}$-TGCT overhanging ends of the (CAG) ${ }_{130-140^{\circ}}$ (CTG) ${ }_{130-140}$ fragment were fractious to ligation. To identify the nature of the overhanging ends that would support efficient ligation, we performed ligations with several short duplex DNAs containing $(\mathrm{CAG})_{\mathrm{n}} \cdot(\mathrm{CTG})_{\mathrm{n}}$ tracts with various overhanging ends (Figure 2A) using T4 DNA ligase at $4^{\circ}, 16^{\circ}$, or $24^{\circ} \mathrm{C}$ (Figure 2B). The ligation of duplex DNA containing $(\mathrm{CAG})_{2} \bullet(\mathrm{CTG})_{2}$

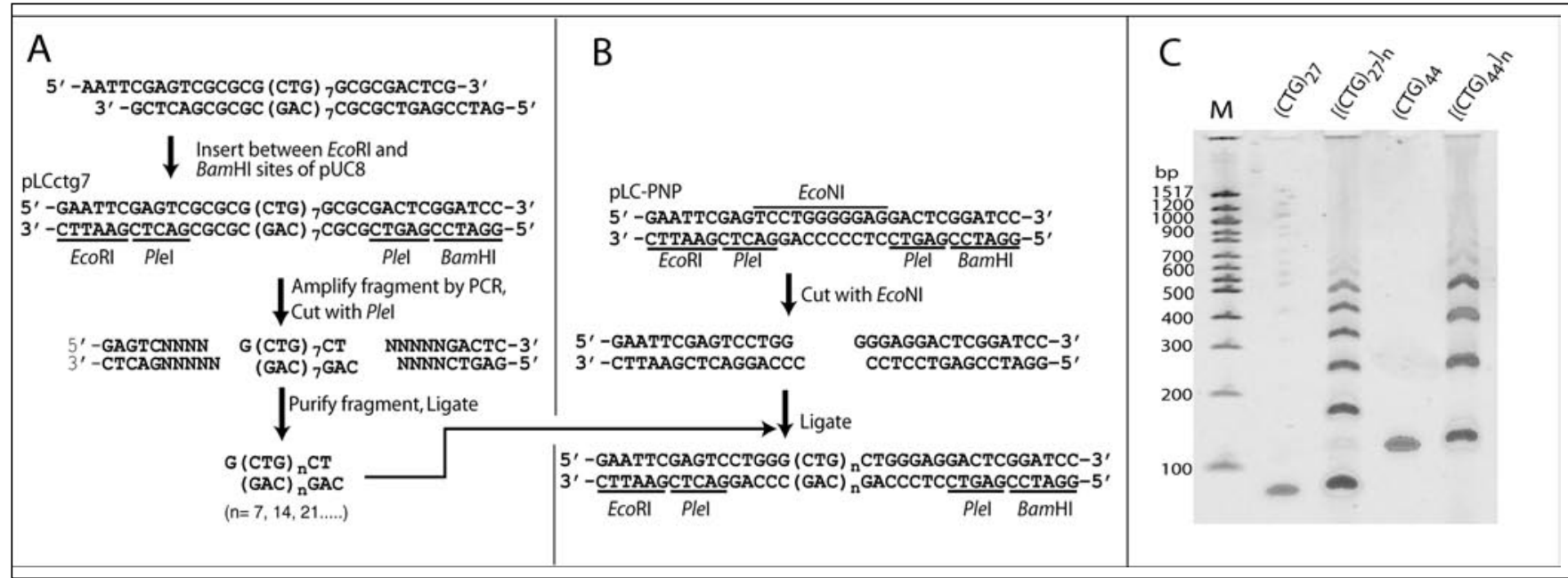

Figure 3. Secondary ligation of cloned trinucleotide repeats containing G/C overhanging ends. (A) Scheme for generation of pure repeat containing fragment from pLC-based plasmids. DNA fragments containing $(\mathrm{CAG})_{\mathrm{n}} \bullet(\mathrm{CTG})_{\mathrm{n}}$ repeats with the EcoRI-PleI and BamHI-PleI adaptors were digested with EcoRI and $B a m \mathrm{HI}$, and the fragments were inserted into pUC8. The repeat sequences were then amplified from the pLC plasmids by PCR. The PCR products were digested with PleI, the pure $(\mathrm{CAG})_{\mathrm{n}}^{\bullet}(\mathrm{CTG})_{\mathrm{n}}$ fragments were gel-purified and then ligated to form oligomers. (B) Purified oligomers were then inserted into plasmid pLC-PNP that had been cut with $E c o$ NI to obtain plasmids containing longer pure repeats. (C) To demonstrate the method, DNA repeats were cut from PCR fragments made from plasmids pLCctg44 and pLCctg27, which contained (CAG) $)_{44^{\bullet}}(\mathrm{CTG})_{44}$ and $(\mathrm{CAG})_{27}{ }^{\bullet}(\mathrm{CTG})_{27}$ repeats, respectively. Shown on a $5 \%$ polyacrylamide gel are DNA repeat fragments that were purified $\left[(\mathrm{CTG})_{27}\right.$ and $\left.(\mathrm{CTG})_{44}\right]$ and then ligated $\left(\left[(\mathrm{CTG})_{27}\right]_{\mathrm{n}}\right.$ and $\left.\left[(\mathrm{CTG})_{44}\right]_{\mathrm{n}}\right)$. Lane M contains the 100-bp molecular weight marker. 
tracts with one-base $\mathrm{G} / \mathrm{C}$ overhanging ends at $4^{\circ}, 16^{\circ}$, or $24^{\circ} \mathrm{C}$ produced a ladder of ligation products (Figure 2B, lane 1), but duplex DNAs containing $(\mathrm{CAG})_{3,6}$, or $12^{\bullet}(\mathrm{CTG})_{3,6}$, or 12 tracts with one-base $\mathrm{A} / \mathrm{T}$ overhanging ends were poorly ligated at $4{ }^{\circ} \mathrm{C}$ (Figure 2B, lanes 2-4). Moreover, duplex DNAs containing the $(\mathrm{CAG})_{3}$ or $6^{\bullet}(\mathrm{CTG})_{3}$ or 6 tracts and a 12-bp unique sequence spacer with one- or four-base (G/C or AGCA/ TGCT) overhanging ends were ligated efficiently (Figure 2B, lanes 5, 6, and $8)$. The ligation of molecules containing the four-base overhang was clearly the most efficient. However, a duplex DNA containing the repeats and the 12-bp spacer with one-base A/T overhanging ends ligated poorly (Figure 2B, lane 7). A duplex DNA containing $(\mathrm{CAG})_{4} \cdot(\mathrm{CTG})_{4}$ with a 6 -bp mismatch spacer and one-base A/T overhanging ends was also ligated poorly (Figure 2B, lane 9). These results support the idea that potential slippage resulting in one-base $\mathrm{A} / \mathrm{T}$ overhanging ends of $(\mathrm{CAG})_{130-140} \bullet$ (CTG $_{130-140}$ fragment may be responsible for the poor ligation of this DNA fragment.

To demonstrate the generality of ligating disease-related DNA repeats containing a single $\mathrm{G} / \mathrm{C}$ overhang, we synthesized $(\mathrm{GAA})_{\mathrm{n}} \bullet(\mathrm{TTC})_{\mathrm{n}},(\mathrm{CCTG})_{\mathrm{n}} \bullet(\mathrm{CAGG})_{\mathrm{n}}$, and $(\text { ATTCT })_{n} \bullet(\text { AGAAT })_{n}$ tracts with single-base $\mathrm{G} / \mathrm{C}$ overhanging ends and performed ligation reactions. With these repeats, more than 15-20 short fragments were ligated to the adaptors (Figure 2C).

\section{Generation of Long (CAG)•(CTG) Repeats}

To clone long $(\mathrm{CAG}) \bullet(\mathrm{CTG})$ repeats, multiple $(\mathrm{CAG})_{7} \bullet(\mathrm{CTG})_{7}$ tracts with $\mathrm{G} / \mathrm{C}$ overhanging ends were ligated to EcoRI-PleI and BamHI-PleI adaptors (shown in Figure 3 and described in Materials and Methods). The DNA was then cut with EcoRI and BamHI, and the EcoRI-BamHI DNA fragment was inserted into pUC8 cut with EcoRI and BamHI, and the plasmid was transformed into bacteria (Figure 3A). Plasmids pLCctg27 and pLCctg44 contain pure $(\mathrm{CAG})_{27} \cdot(\mathrm{CTG})_{27}$ and $(\mathrm{CAG})_{44} \bullet(\mathrm{CTG})_{44}$ repeats, respec- tively, cloned into pUC8. PleI digestion generates the expected fragments of 81 and $132 \mathrm{bp}$, respectively (Figure $3 C)$. Following this initial cloning, two options are available for generating a longer pure repeat DNA fragment. First, the fragment could be liberated by PleI digestion from plasmid purified from $E$. coli. Second, a region of plasmid DNA containing the $(\mathrm{CAG}) \bullet(\mathrm{CTG})$ repeat could be amplified by PCR, and then the pure repeat fragment could be cut out by PleI digestion. Following either procedure, the fragment can be gelpurified for further ligation. Figure 3 shows the PCR procedure for plasmids pLCctg27 and pLCctg44. Following gel purification, the pure $(\mathrm{CAG})_{27^{\bullet}}(\mathrm{CTG})_{27}$ and $\left.(\mathrm{CAG})_{44^{\circ}} \cdot \mathrm{CTG}\right)_{44}$ fragments were ligated into ladders and separated on a $5 \%$ polyacrylamide gel. At least 6-10 fragments were ligated in this experiment.

An additional plasmid, pLC-PNP, was constructed to facilitate a second stage cloning of longer repeats. This plasmid was constructed by ligation of a duplex fragment formed by hybridization of 5'-AATTCGAGTCCTGGGGGAGGACTCG-3' with 5'-GATCCGAGTCCTCCCCCAGGACTCG-3' between the EcoRI and BamHI sites in pUC8 (Figure 3B). Digestion with EcoNI generates a linear plasmid flanked with G/C overhanging ends that will accept multimers of the pure repeat fragments liberated by PleI digestion. Plasmids containing multimers of the original PleI fragments were obtained (data not shown), and these can be cut again with PleI to liberate fragments flanked with $\mathrm{G} / \mathrm{C}$ overhanging ends for another round of ligation, if desired.

\section{DISCUSSION}

The generation of pure diseaseassociated DNA repeat tracts, longer than those stably maintained in bacteria, is important for biophysical studies of these repeats and for use in the introduction of these repeats into mammalian cells to ascertain the biochemical basis for the disease state. In contrast to bacteria where repeat tracts longer than 150-200 repeats are very unstable, cells from patients with these repeat-expansion disorders maintain thousands of repeats in relatively stable fashion. We describe a simple approach for generating diseaseassociated DNA repeats that involves multiple rounds of cloning pure repeat fragments containing single-base $\mathrm{G} / \mathrm{C}$ overhanging ends. This is advisable for several reasons. It is often difficult to obtain large amounts of long repeats, consisting of many ligated fragments, in an initial ligation reaction. Second, very long repeat tracts are difficult to clone, and resulting clones frequently contain repeat interruptions (mutations). By a stepwise cloning approach, the length and purity of the cloned repeat tract can be monitored more easily. Finally, with long pure cloned repeats near the limit of that maintained stably in bacteria (approximately 200 repeats), it is easier to generate pure repeats of very long length (>800 repeats) for use in biochemical studies or for introduction into mammalian cells.

Previous technical difficulties in ligating, cloning, and generating long repeat DNAs may result from strand slippage or the formation of secondary structures at the ends or within DNA repeat sequences. The inability to easily ligate the $(\mathrm{CAG})_{130-140}{ }^{\circ}(\mathrm{CTG})_{130-140}$ fragment with the AGCA/TGCT overhanging end presumably results from facile strand slippage during fragment preparation, converting a four-base overhang to a one-base $\mathrm{A} / \mathrm{T}$ overhang, which, under our conditions, ligates poorly. Slippage can occur by base unpairing or "fraying" at the DNA ends, followed by misalignment, and then transmission of a bubble down the helix. Strand slippage occurs easily in short repeat DNA fragments (26). Many approaches were attempted to prevent slippage and obtain ligation but without success. The limited ligation that occurs during the thermal cycling protocol presumably results from fraying at the ends and slippage, forming a population of ends, some of which are able to hybridize and ligate. Our results strongly suggest that for molecules with an overhang of one repeat length or more, slippage generating a single $\mathrm{A} / \mathrm{T}$ overhang may reduce ligation efficiency. The potential problems to ligating long repeats can be overcome by the design of oligo- 
nucleotides that hybridize to produce DNA fragments with single-base G/C overhanging ends.

\section{ACKNOWLEDGMENTS}

We thank Dr. Charles Thornton for plasmid pACT containing the CTG repeats and for valuable discussions. We thank Vladimir N. Potaman (Center for Genome Research, Institute of Biosciences and Technology, TAMUS HSC) for valuable discussions. This work was supported by grant no. ESO5508 from National Institutes of Environmental Health Sciences to RRS.

\section{COMPETING INTERESTS STATEMENT}

The authors declare no competing interests.

\section{REFERENCES}

1.Cummings, C.J. and H.Y. Zoghbi. 2000. Fourteen and counting: unraveling trinucleotide repeat diseases. Hum. Mol. Genet. 9:909916.

2.Wells, R.D. and S.T.Warren. 1998. Genetic Instabilities and Hereditary Neurological Diseases. Academic Press, San Diego, CA.

3.Sinden, R.R., V.N. Potaman, E.A. Oussatcheva, C.E. Pearson, Y.L. Lyubchenko, and L.S. Shlyakhtenko. 2002. Triplet repeat DNA structures and human genetic disease: dynamic mutations from dynamic DNA. J. Biosci. 27:53-65.

4.Cleary, J.D. and C.E. Pearson. 2003. The contribution of CIS-elements to disease-associated repeat instability: clinical and experimental evidence. Cytogenet. Genome Res. 100:25-55.

5.Mitas, M. 1997. Trinucleotide repeats associated with human disease. Nucleic Acids Res. 25:2245-2253.

6.Pearson, C.E. and R.R. Sinden. 1998. Trinucleotide repeat DNA structures: dynamic mutations from dynamic DNA. Curr. Opin. Struct. Biol. 8:321-330.

7. Darlow, J.M. and D.R.F. Leach. 1998. Secondary structures in d(CGG) and d(CCG) repeat tracts. J. Mol. Biol. 275:3-16.

8.LeProust, E.M., C.E. Pearson, R.R. Sinden, and X. Gao. 2000. Unexpected formation of parallel duplex in GAA and TTC trinucleotide repeats of Friedreich's ataxia. J. Mol. Biol. 302:1063-1080

9.Potaman,V.N., E.A. Oussatcheva, Y.L. Lyubchenko, L.S. Shlyakhtenko, S.I. Bidichandani, T. Ashizawa, and R.R. Sinden. 2004. Length-dependent structure formation in Friedreich ataxia $(\mathrm{GAA})_{\mathrm{n}} \cdot(\mathrm{TTC})_{\mathrm{n}}$ repeats at neutral pH. Nucleic Acids Res. 32:1224-
1231.

10.Potaman, V.N., J.J. Bissler, V.I. Hashem, E.A. Oussatcheva, L. Lu, L.S. Shlyakhtenko, Y.L. Lyubchenko, T. Matsuura, et al. 2003. Unpaired structures in SCA10 $(\text { ATTCT })_{n} \bullet(A G A A T)_{n}$ repeats. J. Mol. Biol. 326:1095-1111.

11.Pearson, C.E. and R.R. Sinden. 1996. Alternative structures in duplex DNA formed within the trinucleotide repeats of the myotonic dystrophy and fragile $\mathrm{X}$ loci. Biochemistry 35:5041-5053.

12.Kang, S., A. Jaworski, K. Ohshima, and R.D. Wells. 1995. Expansion and deletion of CTG triplet repeats from human disease genes are determined by the direction of replication in E. coli. Nat. Genet. 10:213-218.

13.Jaworski, A., W.A. Rosche, R. Gellibolian, S. Kang, M. Shimizu, R.P. Bowater, R.R. Sinden, and R.D. Wells. 1995. Mismatch repair in Escherichia coli enhances instability of $(\mathrm{CTG})_{n}$ repeats from human hereditary diseases. Proc. Natl. Acad. Sci. USA 92:1101911023

14.Bowater, R.P., W.A. Rosche, A. Jaworski, R.R. Sinden, and R.D. Wells. 1996. Relationship between Escherichia coli growth and deletions of $\mathrm{CTG} \bullet \mathrm{CAG}$ triplet repeats in plasmids. J. Mol. Biol. 264:82-96.

15.Schumacher, S., R.P.P. Fuchs, and M. Bichara. 1998. Expansion of CTG repeats from human disease genes is dependent upon replication mechanisms in Escherichia coli-the effect of long patch mismatch repair revisited. J. Mol. Biol. 279:1101-1110.

16.Schmidt, K.H., C.M. Abbott, and D.R. Leach. 2000. Two opposing effects of mismatch repair on CTG repeat instability in Escherichia coli. Mol. Microbiol. 35:463471.

17.Tian, B., R.J. White, T. Xia, S. Welle, D.H. Turner, M.B. Mathews, and C.A. Thornton. 2000. Expanded CUG repeat RNAs form hairpins that activate the double-stranded RNAdependent protein kinase PKR. RNA 6:79-87.

18.Mankodi, A., E. Logigian, L. Callahan, C. McClain, R. White, D. Henderson, M. Krym, and C.A. Thornton. 2000. Myotonic dystrophy in transgenic mice expressing an expanded CUG repeat. Science 289:17691773.

19.Michalik, A., A. Kazantsev, and C. Van Broeckhoven. 2001. Method to introduce stable, expanded, polyglutamine-encoding CAG/ CAA trinucleotide repeats into CAG repeatcontaining genes. BioTechniques 31:250-254.

20.Dorsman, J.C., M. Bremmer-Bout, B. Pepers, G.J. van Ommen, and J.T. Den Dunnen. 2002. Interruption of perfect CAG repeats by CAA triplets improves the stability of glutamine-encoding repeat sequences. BioTechniques 33:976-978.

21.Takahashi, N., N. Sasagawa, K. Suzuki, and S. Ishiura. 1999. Synthesis of long trinucleotide repeats in vitro. Neurosci. Lett. 262:45-48

22.Ordway, J.M. and P.J. Detloff. 1996. In vitro synthesis and cloning of long CAG repeats. BioTechniques 21:609-612.

23.Matsuura, T. and T. Ashizawa. 2002. Polymerase chain reaction amplification of expanded ATTCT repeat in spinocerebellar ataxia type 10. Ann. Neurol. 51:271-272.

24.Sambrook, J. and D.W. Russell. 2001. Molecular Cloning: A Laboratory Manual. CSH Laboratory Press, Cold Spring Harbor, NY.

25.Kochel, T.J. and R.R. Sinden. 1988. Analysis of trimethylpsoralen photoreactivity to Z-DNA provides a general in vivo assay for Z-DNA: analysis of the hypersensitivity of $(\mathrm{GT})_{\mathrm{n}}$ B-Z junctions. BioTechniques 6:532543.

26.Hartenstine, M.J., M.F. Goodman, and J. Petruska. 2000. Base stacking and even/odd behavior of hairpin loops in DNA triplet repeat slippage and expansion with DNA polymerase. J. Biol. Chem. 275:18382-18390.

Received 26 July 2004; accepted 19 August 2004.

Address correspondence to:

Richard R. Sinden

Professor, Center for Genome Research

Laboratory of DNA Structure and Mutagenesis

Institute of Biosciences and Technology

Texas A\&M University System

Health Sciences Center

2121 West Holcombe Blvd.

Houston, TX 77030-3303, USA

e-mail:RSinden@IBT.tamhsc.edu 